\title{
Ssciendo
}

Ethics \& Bioethics (in Central Europe), 2020, 10 (1-2), 96-106

DOI:10.2478/ebce-2020-0010

\section{Perceptions of the importance of business ethics in SMEs: A comparative study of Czech and Slovak entrepreneurs}

\author{
Jaroslav Belás, ${ }^{1}$ Khuramm Ajaz Khan, ${ }^{2}$ Josef Maroušek $^{3}$ \& Zoltán Rozsa ${ }^{4}$
}

\begin{abstract}
This article focuses on the perception of the importance of business ethics among Czech and Slovak entrepreneurs (this includes business owners and managers) within the SME sector. The comparison is based on an analysis of the approach to business ethics according to a set of parameters, namely company size, years in business, and the gender and education of the entrepreneurs. Empirical research was conducted in 2020 on a sample set consisting of 454 respondents in the Czech Republic and 368 respondents in Slovakia. The most important outcome of the research was the finding that business ethics is considered extremely important in both countries. The research results not only revealed that just over $90 \%$ of Czech entrepreneurs and $88 \%$ of Slovak entrepreneurs within the SME sector agreed that they should take into account the moral and ethical consequences of their decisions, but that the structure of their answers was very similar. Also, of interest were the findings that women were more aware of business ethics than their male counterparts, as were those entrepreneurs who possessed a higher education over those with a secondary education.
\end{abstract}

Keywords: business ethics, small and medium-sized enterprises, Czech Republic, Slovakia

\section{Introduction}

Much research is being conducted into business ethics because of the inspirational influence of entrepreneurial behaviour. There is strong motivation to act ethically among entrepreneurs. To understand why, it is important to determine what the perceptions and attitudes behind such motives are. The reasons lie in the responsibility of entrepreneurs (this includes business owners and managers) for the development and growth of a company, for maximizing profitability, for keeping investors happy with good returns, for improving customer loyalty through new products and services, and for productivity gains by motivating employees. Likewise, they are responsible for planning, strategy development, resource management, competitivity, decision making, and overall business operations (Kearney, Harrington \& Kelliher, 2019). The crucial role of entrepreneurs, their approaches and attitudes towards the utilisation of natural resources, the effects on the environment, and its consequences on society and people, cannot be separated from daily business operations (Kolb, 2018). Jamnik (2011) states that entrepreneurs routinely encounter ethical issues in their work, and that it is very rare for ethical issues to be absent in their decision making. The diverse roles of business owners and managers cannot, therefore, be overlooked because of the negative and positive moral and ethical consequences of their actions and decisions on businesses, the economy, people, society and the environment. Furthermore, cut-throat competition, company survival, risk of failure, limited resources, etc., all pose challenges, thereby conflicting the priorities of entrepreneurs. The dilemma of deciding what is right and what is wrong is therefore not only limited to big corporations, but also plays a role in the day to day operations of small businesses (Robinson, Davidson, Van Der Mescht \& Court, 2007). Another study confirmed that entrepreneurs are increasingly facing ethical decisionmaking challenges (Enyioko, 2017). At present, they not only have direct responsibility to

\footnotetext{
${ }^{1}$ Tomas Bata University in Zlín, Center for Applied Economic Research, Zlín (Czech Republic); belas@utb.cz

${ }^{2}$ Tomas Bata University in Zlín, Faculty of Management and Economics, Zlín (Czech Republic); khan@utb.cz

3 Institute of Technology and Business, Faculty of Technology, České Budějovice (Czech Republic); marousek@mail.vstecb.cz

${ }^{4}$ Alexander Dubček University in Trenčín, Faculty of Social and Economic Relations, Trenčín (Slovak Republic); zoltan.rozsa@tnuni.sk
} 
maximise stakeholders' returns and improve business performance, but also to make decisions that do not negatively affect society, the economy or the environment (Carroll, 1991).

An entrepreneur's personal characteristics, overall values, ethical behaviour, decisionmaking style, differentiation between right and wrong, also cannot be separated from an SMEs' daily business operations. The smaller the business, the more significant the entrepreneur's influence (Öksuzoglu-Guven, 2015). This study therefore focuses on SMEs because the economic growth of the nation can be measured by the growth of SMEs (Rahman, Belas, Kliestik \& Tyll, 2017; Taiwo, Ayodeji \& Yusuf, 2013). Furthermore, the growing economic importance of SMEs means that ethical challenges are no longer limited to big corporations (Robinson et al., 2007). This means that investigating the factors that influence business ethics and the ethical behaviour of entrepreneurs within the SME sector, and the impact thereof, is warranted.

This study assesses the state of ethical decision-making in SMEs in the Czech Republic and Slovakia. The novelty and excellence of the research lies in the fact that it is based on the attitudes of entrepreneurs themselves and on a representative sample of respondents.

The study is divided into four parts. The first part sets out the theoretical background and factors that affect business ethics, as well as the roles and demographics of entrepreneurs. The second part covers the aims, research methodology and data. The third part consists of analysis and a discussion of the results, with the conclusions presented in part four.

\section{Theoretical background}

An entrepreneur's decision-making process is not influenced by one factor, but rather by a complex system of factors that may have multiple impacts. This therefore requires a multifacetted approach to evaluating an entrepreneur's decision making, one that takes into consideration factors such as human nature, workplace relationships, competition, etc. (Öksüzoğlu-Güven, 2015). Hence, the literature review is split into two parts. The first part focuses on important factors affecting ethical decision-making in business, as well as on the roles and perceptions of entrepreneurs and the impact and consequences of moral and ethical decision-making on business performance, the environment and society. The second part looks to identify how demographic factors, such as gender, age and education, influence the ethical decision-making (Öksüzoğlu-Güven, 2015) of entrepreneurs within the SME sector.

According to Lewis (1985),business ethics is about the moral rules, code of conduct, principles and standards that guide correct and truthful behaviour in specific situations. This definition identifies the ethical ways in which to manage a business and therefore provides guidance to business owners and managers with regard to determining, drafting and following their own set of rules, both personal and organisational, for conducting their own business activities. In their study, San-Jose \& Retolaza (2018) state that there are three levels of business ethics, namely individual, organisational and macro. This particular explanation suggests that business ethics has wide implications. To be an ethical manager, you must possess the characteristics of a moral person, a moral manager, and a moral entrepreneur (Kaptein, 2019). According to Iacovino (2002), business ethics is about the difference between right and wrong, it is about following acceptable and justified rules and regulations, and the truthful behaviour of business owners and managers with regards to upholding the law, respecting people and the environment. Adkins \& Radtke (2004) highlight a number of unethical corporate incidences by owners and managers that negatively affected the environment and stakeholders. Ethics is about human conduct or human actions. Ethical decision-making is a unique human activity because it is related to the human ability to find a reason to justify and to investigate their actions and activities, and to find self-fulfilment as part of a social cluster or, in the contemporary world, as a member of society as a whole. Ethics is also not just about how a human feels about something. Instead, it is a rational process that may become normal or instinctive once a set of 
values is defined for constant application (Iacovino, 2002). Studies also show that managers and employees have basic knowledge of and favourable attitudes towards the concept of social responsibility (Milenkovska, Petrovska \& Stoilkovska, 2019).

The interpretation of ethical issues has also drastically changed in the last few years. If a company wants to be perceived as being trustworthy and a dignified member of the business community, it must reflect and constantly implement the increasing standards being applied to business ethics (Sroka \& Szántó, 2018). Many studies have shown that companies that show concern for social and environmental issues can attract consumers to their products and services because they appreciate such initiatives. Pivato et al. (2007) state that a company's social contribution builds trust, which is reflected in a positive impact on brand loyalty. In a similar vein, Turyakira (2018) concludes that in order to be competitive in the market and protect their business interests, business organisations and managers must learn to behave ethically. This also relates to other organisational issues such as the utilisation of natural resources, the creation of jobs and the payment of taxes. In other words, the performance of their legal and economic responsibilities. Within this context, the ethical behaviour of a company is defined by the rules, code of conduct, procedures and policies it should uphold and apply to managerial decisionmaking. However, the responsibility this entails for putting all the aforementioned into practice depends very much on how managers and business owners perceive and implement them (Sexty, 1995).

SMEs and entrepreneurs are the driving force behind the growth of economies. RibeiroSoriano (2017) concluded that the key people in SMEs are behind the functioning of an economy and contribute to a nation's economic development.

A study covering the V4 countries found that business ethics is considered to be an important factor affecting both the profitability and success of a business. The same study also revealed the expectation that the role of business ethics will expand in the future (Sroka \& Lörinczy, 2015). Some studies have found that business ethics has a positive effect on business competitivity (Turyakira, 2018), brand loyalty and trust (Pivato et al., 2007), and business trustworthiness and dignity (Sroka \& Szántó, 2018).

Many studies have also found that demographic factors, such as the gender, age and education of entrepreneurs, influence ethical business management (Dalton \& Ortegren, 2011; Marín, Nicolás \& Rubio, 2019; Peterson, Rhoads \& Vaught, 2001; Serwinek, 1992). It is therefore relevant to study how these and other demographic factors influence the perception and implementation of business ethics and the ethical behaviour of entrepreneurs, business owners and managers.

A recent study on the social orientation of entrepreneurs found that this is stronger in women, in the more educated, and in older people, although the latter required further research (Marín et al., 2019). Although gender is considered to be an important factor in determining attitudes to ethics, a study by Serwinek (1992) failed to detect any strong differences in perception between men and women. Another study found an indirect link between gender and ethical decision-making, but advocated for further research into the issue due to the mixed outcomes of previous studies. Earlier studies found that gender influences ethical responses, whereby women were reported to be more sensitive to social issues than men. However, when taking the overall findings into consideration, it is hard to draw a specific conclusion with regards to the ethical decision-making differences between men and women (Dalton \& Ortegren, 2011). This conclusion reflects our own findings, which also revealed mixed results for almost all of the chosen demographic variables.

However, a study into environmental issues, e.g. buying organic food, recycling, etc., revealed that women show deeper concern than men. Women display better ethical behaviour towards environmental protection (Hunter, Hatch \& Johnson, 2004). Another study by Peterson, Rhoads \& Vaught (2001) tested the relationship between the gender and age of 
business professionals and the influence of external factors on their ethical beliefs. The study outcomes indicated that young female professionals possess higher levels of ethical beliefs than their male equivalents, and that older males only display a slightly higher level than their younger equivalents. Age and gender are therefore both relevant to ethical beliefs. The study found that the most significant predictor is age (Serwinek, 1992). A study by Loe, Ferrell \& Mansfield (2000) found that the majority of research conducted into gender differences and ethical sensitivity either concluded that there were no significant gender differences or that females are more ethically sensitive than males. The same study also included an analysis of eighteen studies into the relationship between education and ethical decision-making. Half of them found no significant relationship, whereas the remaining ones were inconclusive. However, a positive correlation was found to exist between age and ethical decision-making.

Grbac \& Lončarić (2009) conducted research among managers of Croatian firms and found that ethics and social responsibility were considered to be highly important for business success. They found a positive relationship between the perception of ethics and the role of social responsibility in the productivity, performance and profitability of a business. A study into the influence of organisational ethics programmes found that ethics training helps to boost the trust of managers in such programmes. Ethics programmes can be used as a management tool to prevent unethical actions, improve employee conduct, differentiate between desired and undesired patterns of behaviour, and improve organisational culture in order to improve day to day operations (Remišová, Lašáková \& Kirchmayer, 2019).

A study by Sroka \& Szántó (2018) looked into the perceived ethical behaviour of 48 companies from three different industrial sectors, pharmaceuticals, tobacco and alcohol, in Poland and Hungary. It was found that business ethics is considered an important factor for business success and corporate image. No differences were found with regard to perceived ethical behaviour in Poland and Hungary. According to Chen-Fong (2002), when a company wants to implement a higher level of business ethics and enhance the opportunities for ethical decision-making by employees, the company's non-financial organisational performance improves. Improvements in organisational performance are directly dependent on the application of high-level ethics at both the individual and corporate level. A study by Lam \& Shi (2008) into the moral judgement and ethical attitudes of working people found diverse influences of a number of demographic factors on law- and social-based ethical issues. The outcomes failed to support the assumption that males are more sensitive towards law-based ethical issues and females more sensitive towards social-based ethical issues. Another outcome of the study was that females have a lower acceptance threshold towards unethical behaviours in both areas, but failed to find a statistically significant relationship between gender or university education on attitudes to ethics. It is clear that the onus of ethical decision-making falls on business owners and managers. Within this context, and that of the literature review, it is therefore logical to study whether demographic factors influence their ethical decisionmaking and how they view the moral and ethical consequences of the outcomes of that process. This argumentation forms the basis for the present paper

\section{Aims, research methodology and data}

The aim of this article is to determine how important business ethics is to Czech and Slovak entrepreneurs (this includes business owners and managers) within the SME sector. The comparison is based on an analysis of the approach to business ethics according to a set of parameters, namely company size, years in business, and the gender and education of the entrepreneurs.

Empirical research was conducted among SMEs from October 2019 to March 2020 in the Czech Republic (CR) and the Slovak Republic (SR) using an on-line questionnaire. From the Cribis database, we randomly selected a sample of respondents whom we addressed by e-mail. 
In total, more than 8,000 companies were approached in the Czech Republic, and more than 10,000 in the Slovak Republic. The total number of accepted questionnaires for the Czech Republic was 454 and for the Slovak Republic 368. The questionnaires were filled in by company owners or top managers. For the CR, this concerned 354 company owners and 100 managers. For Slovakia, 285 and 83 respectively.

In summary, the CR sample set included: 290 micro-companies, 107 small companies and 57 medium-sized ones. Years in business: 119 companies have been in business for up to 10 years and 335 for over 10 years. The educational level of the entrepreneurs was as follows: 231 indicated secondary education and 223 indicated higher education. Gender participation was: 323 men and 131 women.

In summary, the SR sample set included:216 micro-companies, 106 small companies, and 46 medium-sized ones. Years in business: 105 companies have been in business for up to 10 years and 263 for over 10 years. The educational level of entrepreneurs was as follows: 77 indicated secondary education and 291 indicated higher education. Gender participation was: 253 men and 115 women.

The assertion: "entrepreneurs (this includes business owners and managers) should take into account the moral and ethical consequences of their decisions" was the focus of the research. Respondents could choose from the following responses: strongly agree, agree, neither agree nor disagree, disagree, and strongly disagree.

Based on the estimation method, the following scientific hypotheses were formulated:

H1: Business owners (managers) should take into account the moral and ethical consequences of their decisions. A maximum of $70 \%$ of respondents in the Czech Republic and Slovakia agree with this assertion.

H1a: There are no statistically significant differences between the CR and the SR in the overall response structure and in the positive attitudes of entrepreneurs when evaluating this assertion.

$\mathrm{H} 2$ : There are no statistically significant differences in the positive attitudes of entrepreneurs when evaluating this assertion according to the given parameters (company size, years in business, highest level of completed education) in the CR.

$\mathrm{H} 2 \mathrm{a}$ : There are statistically significant differences in the positive attitudes of entrepreneurs when evaluating this assertion by gender in the $\mathrm{CR}$.

H3: There are no statistically significant differences in the positive attitudes of entrepreneurs when evaluating this assertion according to the given parameters (company size, years in business, highest level of completed education) in the SR.

H3a: There are statistically significant differences in the positive attitudes of entrepreneurs when evaluating this assertion by gender in the SR.

For descriptive statistics (percentages, means), the Chi-square and Z-score methods were used to evaluate the defined scientific hypotheses. Statistically significant differences were compared through Pearson statistics at a significance level of 5\%. The calculations were performed using free software available on the Internet.

\section{Results and discussion}

The following tables show the results of the empirical research, as well as the results of the statistical processing thereof.

Table 1: Entrepreneurs'views on business ethics in the Czech Republic and Slovakia

\begin{tabular}{|l|c|c|c|}
\hline $\begin{array}{l}\text { Entrepreneurs (including business } \\
\text { owners and managers) should take } \\
\text { into account the moral and ethical } \\
\text { consequences of their decisions. }\end{array}$ & 454 & 368 & $\begin{array}{c}\text { Z-score/p- } \\
\text { value } \\
\text { CR/SR }\end{array}$ \\
\hline
\end{tabular}




\begin{tabular}{|l|c|c|c|}
\hline 1. Strongly agree & 263 & 192 & 0.4122 \\
\hline 2. Agree & 146 & 133 & \\
\hline 1+2 together: percentage, quantity & $90.01 / 409$ & $88.32 / 325$ & \\
\hline 3. Neither agree nor disagree & 31 & 35 & \\
\hline 4. Disagree & 9 & 6 & \\
\hline 5. Strongly disagree. & 5 & 2 & \\
\hline Chi-square/ p-value: $4.8687 / 0.3010$ & & & \\
\hline
\end{tabular}

Source: Authors

In the Czech Republic, up to $90.01 \%$ of entrepreneurs agreed with the assertion that they, as a group, should take into account the moral and ethical consequences of their decisions. For the Slovak Republic, this stood at $88.32 \%$.

The Chi-square test value ( $\mathrm{p}$-value $=0.3010)$ confirmed that there is no statistically significant difference in the overall response structure between the respondents in the Czech Republic and Slovakia. We can therefore state that the weight of the answers of the Czech and Slovak respondents for the defined parameters is approximately the same.

The Z-score ( $p$-value $=0.4122$ ) for the test criterion confirmed that there are no statistically significant differences in the positive responses of entrepreneurs in the Czech Republic and Slovakia. We can therefore state that the positive responses in both countries are approximately the same.

H1 was refuted.

H1a was confirmed.

Table 2: Entrepreneurs' views on business ethics in the Czech Republic

\begin{tabular}{|c|c|c|c|}
\hline $\begin{array}{l}\text { Entrepreneurs (including business } \\
\text { owners and managers) should take into } \\
\text { account the moral and ethical } \\
\text { consequences of their decisions. }\end{array}$ & $\begin{array}{l}\text { Micro/- } \\
\text { 10/M/SE }\end{array}$ & $\begin{array}{c}\text { Others/10+/W/ } \\
\text { UE }\end{array}$ & $\begin{array}{l}\mathrm{Z} \text {-score } \\
\text { p-value }\end{array}$ \\
\hline 1. Strongly agree & $\begin{array}{c}183 / 64 / 187 / 13 \\
2\end{array}$ & $80 / 199 / 76$ & $* 0.2891$ \\
\hline 2. Agree & $75 / 44 / 98 / 72$ & $71 / 102 / 48$ & $* * 0.7795$ \\
\hline $\begin{array}{l}\text { 1+2 together: } \\
\text { quantity } \\
\text { entage }\end{array}$ & $\begin{array}{c}258 / 108 / 285 / 2 \\
04 \\
89 / 91 / 88 / 88\end{array}$ & $\begin{array}{c}151 / 301 / 124 / 20 \\
5 \quad 92 / 90 / 95 / 92\end{array}$ & $\begin{array}{c}* * * 0.038 \\
5 \\
* * * * 0.19 \\
71\end{array}$ \\
\hline
\end{tabular}

Source: Authors

Notes: comparison by*company size (micro-, small and medium-sized), ${ }^{* *}$ years in business (up to 10 years and over 10 years), ${ }^{* * *}$ gender, ${ }^{* * * *}$ completed education(secondary education and higher education).

The highest level of agreement with the assertion was found among female entrepreneurs (95\%) and the lowest level among men and entrepreneurs with secondary education (88\%).

The Z-score ( $\mathrm{p}$-value $=0.2891 / 0.7795 / 0.1971)$ for the test criterion confirmed that there are no statistically significant differences in the positive responses of entrepreneurs based on company size, years in business, and the entrepreneurs' education. 
The Z-score $(p$-value $=0.0385)$ for the test criterion confirmed that there are statistically significant differences in the positive responses of entrepreneurs based on their gender. Women agreed more intensely with the assertion.

$\mathrm{H} 2$ was confirmed.

H2a was confirmed.

Table 3: Entrepreneurs' views on business ethics in the Slovak Republic

\begin{tabular}{|l|c|c|c|}
\hline $\begin{array}{l}\text { Entrepreneurs (including } \\
\text { business owners and managers) } \\
\text { should take into account the } \\
\text { moral and ethical consequences } \\
\text { of their decisions. }\end{array}$ & $\begin{array}{c}\text { Micro/- } \\
10 / \mathrm{M} / \mathrm{SE}\end{array}$ & Others/10+/W/UE & $\begin{array}{l}\text { Z-score } \\
\text { p-value }\end{array}$ \\
\hline $\begin{array}{l}\text { 1. Strongly agree } \\
\text { 2. Agree }\end{array}$ & $\begin{array}{c}116 / 50 / 133 / 3 \\
2 /\end{array}$ & $76 / 142 / 59 / 160$ & $* 0.3628$ \\
\hline $\begin{array}{l}1+2 \text { together: } \\
\text { quantity } \\
\text { ntage }\end{array}$ & $\begin{array}{c}188 / 90 / 225 / 6 \\
3\end{array}$ & $137 / 235 / 100 / 26290 / 89 / 8$ & $* * * 0.582$ \\
& $87 / 86 / 89 / 82$ & $7 / 90$ & $* 3 * 0.04$ \\
\hline
\end{tabular}

Source: Authors

Notes: comparison by *company size (micro-, small and medium-sized), ${ }^{* *}$ years in business (up to 10 years and over 10 years), ${ }^{* * *}$ gender, ${ }^{* * * *}$ completed education (secondary education and higher education).

The highest level of agreement with the assertion was found in larger companies and among entrepreneurs with a higher education (90\%), and the lowest level of agreement among entrepreneurs with a secondary education $(82 \%)$.

The Z-score ( $p$-value $=0.0455)$ for the test criterion confirmed that there are statistically significant differences in the positive responses of entrepreneurs in Slovakia based on their level of education. Those entrepreneurs with a higher education showed a higher level of agreement with the assertion.

The Z-score $(p$-value $=0.0385)$ for the test criterion confirmed that there are statistically significant differences in the positive responses of entrepreneurs based on their gender.

H3 was refuted.

H3a was refuted.

The analysis, which is based on relatively robust empirical research in both countries, provides surprising results. They reveal that up to $90.01 \%$ of Czech entrepreneurs and managers and $88.32 \%$ of Slovak entrepreneurs and managers agree with the assertion that they should take into account the moral and ethical consequences of their decisions.

Several factors may explain this phenomenon. For example, it is possible that the respondents purely expressed their opinion knowing that it does not oblige them to act ethically in their business activities. An alternative explanation is that on some issues, people's selfassessment is highly subjective and that some of the respondents see themselves in a better light.

The Slovak Compliance Circle survey of 2014 confirmed this trend; entrepreneurs and managers rated the overall situation concerning business ethics in Slovakia with an average score of $3.3(1=$ best and $5=$ worst $)$, but, within their own industry, rated the situation with a score of 2.7, and within their own company with a score of 1.9 (Slovak Compliance Circle, 
2015). While the perception of the market situation was slightly negative, there was considerable optimism in their self-evaluation. The difference between the average assessment of the overall market situation and that of the company itself was approximately $30 \%$. The survey also revealed that $65 \%$ of respondents believed that strict adherence to ethical behaviour would not lead to the failure of their business and that $43 \%$ of respondents considered the consistent application of ethical principles in their own company was a basis for building a competitive advantage that would bring success to the company in the long term.

A study of managers' opinions on business ethics in Iceland revealed that only $42 \%$ of respondents agreed or strongly agreed that Icelandic firms practice good business ethics, with $26 \%$ disagreeing or strongly disagreeing (Sigurjonsson, Arnardottir, Vaiman \& Rikhardsson, 2015).A similar study in Italy found that only $38.8 \%$ of business owners and managers agreed that integrity in their commercial practices (honesty and truthfulness in publicity, fair delivery conditions) was a priority (D’Andrea \& Montanini, 2015).

In contrast, a study in Romania found that $80 \%$ of business owners and managers disagreed with the statement that moral and ethical values are irrelevant for business, that $41 \%$ agreed that competition creates difficulties when making ethical decisions, that $68 \%$ disagreed that profit should supersede ethics, and that $92 \%$ agreed that there is a long-term correlation between ethics and profits (Echevarria-Cruz, Vaduva, Fotea \& Neagoie, 2015).

According to joint research conducted by EY and the Association of Small and MediumSized Enterprises and Crafts in the Czech Republic, up to 35\% of Czech entrepreneurs and managers stated that it is not possible to get a public contract without a bribe and that for $81 \%$ of them, corruption is a widespread phenomenon in society (EY \& AMSP ČR, 2019).

Burduja \& Zaharia (2019) found that nearly half (47.1\%) of all business leaders believed that the "high prevalence of unethical behaviour in society" is a major hurdle to tackling corruption in privately owned businesses.

The presented results, which confirm the high interest in ethical aspects of entrepreneurship, counter the criticisms of the concept and role of Corporate Social Responsibility (CSR) in several economic theories. Within these theories, entrepreneurship and economics takes priority over ethics and environmental issues.

A study in Romania among business leaders and managers of micro-, small, medium-sized and large enterprises found that, on a scale of 1 to $5(1=$ not important and $5=$ very important $)$, economic responsibilities were rated the most important (4.57), followed by legal responsibilities (4.21) and ethical responsibilities (3.94), and that philanthropic responsibilities were the least important (3.44) (Gorski, 2017).

In the Czech Republic, we found that a higher number of women agreed with the assertion that entrepreneurs (including business owners and managers) should take into account the moral and ethical consequences of their decisions. This is not particularly surprising because women are generally perceived as being more responsible, empathetic, and more socially oriented in the economic environment, albeit with a higher risk aversion. However, what is surprising is that we did not find a similar trend in Slovakia.

The perception of women referred to above is reflected, for example, in the scoring models of banks, which rate the credit history of men and women differently. Women are considered to be more responsible, so they receive a better rating from banks than men. The regular payment of instalments on loans is, beyond the economic aspects thereof, considered to be an ethical issue.

Among the entrepreneurs in the SR sample set, those with a higher education showed a higher level of agreement with the assertion than those with a secondary school education. This is not surprising because it is assumed that university education opens up additional information channels that shape the attitudes of entrepreneurs with regard to how they should conduct their business activities in terms of business ethics, the environment and society. 
This last point has been confirmed by research which clearly shows that university-educated entrepreneurs achieve better business results and have a better skills set for keeping a company on the market compared to entrepreneurs with only a secondary education. However, it is not gratifying to know that the interest of university students in going into business is low. For example, research conducted in 2016, showed that in the Czech Republic, only $49 \%$ of university students studying economic fields were interested in becoming entrepreneurs, compared to 59\% in Slovakia (Belas et al., 2017).

\section{Conclusions and limitations}

This article aimed to present the views of entrepreneurs in the Czech Republic and Slovakia with regard to the importance of business ethics and to bring new knowledge about this field specifically with regard to the issue within SMEs. To achieve this, a comparative study was conducted of the attitudes of entrepreneurs (including business owners and managers) in both countries according to defined parameters.

The primary result of the research was that the importance of business ethics is viewed very highly in both countries, with the structure of the answers of Czech and Slovak entrepreneurs being found to be very similar. In addition, women were found to have a higher awareness of business ethics than men, as were entrepreneurs and managers with a higher education compared to those who have a secondary education.

Our research had some limitations. It is therefore within this context that the presented results should be viewed. Although we randomly selected respondents and conducted research on a representative sample, this is not and cannot be perceived as absolutely valid. The fact that the research was carried out during a favourable phase of economic development can also be viewed as a significant limitation. After all, during an economic crisis, it is to be expected that entrepreneurs' opinions may differ to those they currently hold.

Further research will focus on a detailed examination of ethical issues in business, particularly within the context of the economic viability of SMEs, in order to present the theoretical possibilities of increasing the ethical and social level of business activities without incurring economic losses.

\section{References}

ADKINS, N. \& RADTKE, R. R. (2004): Students' and faculty members' perceptions of the importance of business ethics and accounting ethics education: Is there an expectations gap? In: Journal of Business Ethics, 51(3), pp. 279-300.

BELAS, J, DVORSKY, J., TYLL, L. \& ZVARIKOVA, K. (2017): Entrepreneurship of university students: Important factors and the propensity for entrepreneurship. In: Administratiesi Management Public, (28), pp. 6-25.

BURDUJA, S. I. \& ZAHARIA, R. M. (2019): Romanian business leaders' perceptions of business-to-business corruption: Leading more responsible businesses? In: Sustainability (Switzerland), 11(20), p. 27.

CARROLL, A. B. (1991): The pyramid of corporate social responsibility: Toward the moral management of organizational stakeholders. In: Business Horizons, 34(4), pp. 39-48.

D'ANDREA, A. \& MONTANINI, L. (2015): Corporate social responsibility practices in Italian SMEs. In: Journal of Business and Economics, 6(12), pp. 2040-2053.

CHEN-FONG, W. (2002): The relationship of ethical decision-making to business ethics and performance in Taiwan. In: Journal of Business Ethics, 35(3), pp. 163-176.

DALTON, D. \& ORTEGREN, M. (2011): Gender differences in ethics research: The importance of controlling for the social desirability response bias. In: Journal of Business Ethics, 103(1), pp. 73-93. 
ECHEVARRIA-CRUZ, S., VADUVA, S., FOTEA, I. \& NEAGOIE, D. (2015): Business ethics and corporate social responsibility attitudes among SME leaders in Romania. In: Proceedings of the 9th International Management Conference: Management and Innovation for Competitive Advantage. Bucharest: b.n., pp. 830-839.

ENYIOKO, N. C. (2017): Ethical characterisation of entrepreneurs and their organisational growth in Nigeria. In: SSRN Electronic Journal, pp. 1-20.

EY \& AMSP ČR. (2019): Podnikatelé a vnímání korupce v České republice. [Businessmen and perception of corruption in Czech Republic]. Praha: AMSP ČR.

GORSKI, H. (2017): Leadership and corporate social responsibility. In: International Conference Knowledge-Based Organization, 23(1), pp. 372-377.

GRBAC, B. \& LONČARIČ, D. (2009): Ethics, social responsibility and business performance in a transition economy. In: EuroMed Journal of Business, 4(2), pp. 143-158.

HUNTER, L. M., HATCG, A. \& JOHNSON, A. (2004): Cross-national gender variation in environmental behaviors. In: Social Science Quarterly, 85(3), pp. 677-694.

Chi-SQUARE TEST CALCULATOR. [online] [Retrieved March 10, 2020] [Available at: https://www.socscistatistics.com/tests/chisquare2/default2.aspx

IACOVINO, L. (2002): Ethical principles and information professionals: Theory, practice and education. In: Australian Academic and Research Libraries, 33(2), pp. 57-74.

JAMNIK, A. (2011): The challenges of business ethics - management and the question of ethics. In: Tourism and Hospitality Management, 17(1), pp. 141-152.

KAPTEIN, M. (2019): The moral entrepreneur: A new component of ethical leadership. In: Journal of Business Ethics, 156(4), pp. 1135-1150.

KEARNEY, A., HARRINGTON, D. \& KELLIHER, F. (2019): Strategizing in the micro firm: A 'strategy as practice' framework. In: Industry and Higher Education, 33(1), pp. 6-17.

KOLB, R. W. (2018): Ethical role of the manager. In: R. W. Kolb (ed.): The SAGE Encyclopedia of Business Ethics and Society. Thousand Oaks, CA: SAGE, pp. 1-6.

LAM, K. C. \& SHI, G. (2008): Factors affecting ethical attitudes in Mainland China and Hong Kong. In: Journal of Business Ethics, 77(4), pp. 463-479.

LOE, T. W., FERRELL, L. \& MANSFIELD, P. (2000): A review of empirical studies assessing ethical decision making in business Terry. In: Journal of Business Ethics, 25(3), pp. 185-204.

MARÍN, L., NICOLÁS, C. \& RUBIO, A. (2019): How gender, age and education influence the entrepreneur's social orientation: The moderating effect of economic development. In: Sustainability (Switzerland), 11(17), pp. 1-16

MILENKOVSKA, V., PETROVSKA, J. \& STOILKOVSKA, A. (2019): Positive attitude towards business ethics and social responsibility for improving corporate image. In: UTMS Journal of Economics, 10(1), pp. 97-107.

ÖKSUZOGLU-GUVEN, G. (2015): Entrepreneurial ethical decision making. In: D. E. Palmer (ed.): Handbook of Research on Business Ethics and Corporate Responsibilities. Hershey, PA: IGI Global, pp. 106-122.

PETERSON, D., RHOADS, A. \& VAUGHT, B. C. (2001): Ethical beliefs of business professionals: A study of gender, age and external factors. In: Journal of Business Ethics, 31(3), pp. 225-232.

LEWIS, P. V. (1985): Defining business ethics: Like nailing jello to a wall. In: Journal of Business Ethics, 4(2), pp. 377-383.

PIVATO, S., MISANI, N. \& TENCATI, A. (2007): The impact of corporate social responsibility on consumer trust: the case of organic food. In: Business Ethics: A European Review, 17(1), pp. 3-12.

RAHMAN, A., BELAS, J., KLIESTIK, T. \& TYLL, L. (2017): Collateral requirements for SME loans: empirical evidence from the Visegrad countries. In: Journal of Business Economics and Management, 18(4), pp. 650-675. 
REMIŠOVÁ, A., LAŠÁKOVÁ, A. \& KIRCHMAYER, Z. (2019): Influence of formal ethics program components on managerial ethical behavior. In: Journal of Business Ethics, 160(1), pp. $151-166$.

RIBEIRO-SORIANO, D. (2017): Small business and entrepreneurship: their role in economic and social development. In: Entrepreneurship \& Regional Development, 29(1-2), pp. 1-3.

ROBINSON, D. A., DAVIDSSON, P., VAN DER MESCHT, H. \& COURT, P. (2007): How entrepreneurs deal with ethical challenges: An application of the business ethics synergy star technique. In: Journal of Business Ethics, 71(4), pp. 411-423.

SAN-JOSE, L. \& RETOLAZA, J. L. (2018): European business ethics agenda based on a Delphi analysis. In: European Journal of Futures Research, 6(1), Article 12.

SERWINEK, P. J. (1992): Demographic \& related differences in ethical views among small businesses. In: Journal of Business Ethics, 11(7), pp. 555-566.

SEXTY, R. W. (1995):Canadian Business and Society. Scarborough, Ont.: Prentice Hall.

SIGURJONSSON, T. O., ARNARDOTTIR, A. A., VAIMAN, V. \& RIKHARDSSON, P. (2015): Managers' views on ethics education in business schools: An empirical study. In: Journal of Business Ethics, 130(1), pp. 1-13.

SLOVAK COMPLIANCE CIRCLE. (2015): Vnímanie podnikatel'skej etiky na Slovensku [The perception of business ethics in Slovakia]. Bratislava: SCC.

SROKA, W. \& LÖRINCZY, M. (2015): The perception of ethics in business: Analysis of Research Results. In: Procedia Economics and Finance, 34(15), pp. 156-163.

SROKA, W. \& SZÁNTÓ, R. (2018): Corporate social responsibility and business ethics in controversial sectors: Analysis of research results. In: Journal of Entrepreneurship, Management and Innovation, 14(3), pp. 111-126.

TAIWO, M. A., AYODEJI, A. M. \& YUSUF, B. A. (2013): Impact of small and medium enterprises on economic growth and development. In: American Journal of Business and Management, 2(1), pp. 18-22.

TURYAKIRA, P. K. (2018): Ethical practices of small and medium-sized enterprises in developing countries: Literature analysis. In: South African Journal of Economic and Management Sciences, 21(1), pp. 1-7.

Z SCORE CALCULATOR FOR 2 POPULATION PROPORTIONS. [online] [Retrieved March 12, 2020] Available at: https://www.socscistatistics.com/tests/ztest/default2.aspx 